\author{
Original Article
}

\title{
Study of human knowledge and attitude toward urban birds in Faisalabad city, Pakistan
}

\author{
Estudo do conhecimento humano e da atitude em relação às aves urbanas na cidade \\ de Faisalabad, Paquistão
}

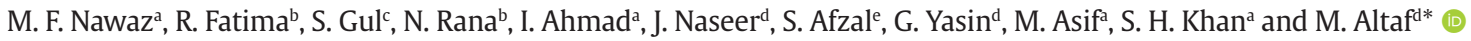 \\ aUniversity of Agriculture, Department of Forestry and Range Management, Faisalabad, Pakistan \\ bUniversity of Agriculture, Department of Zoology, Wildlife and Fisheries, Faisalabad, Pakistan \\ 'University of Karachi, Department of Botany, Karachi, Pakistan \\ dThe Islamia University of Bahawalpur, Department of Forestry, Range and Wildlife Management, Bahawalpur, Pakistan \\ eUniversity of Sargodha, Department of Forestry, Range Management and Wildlife, Sargodha, Pakistan
}

\begin{abstract}
Birds are very valuable indicators of species richness and endemic patterns in a specified ecosystem, which eventually help the scientist to measure the environmental degradation. The aim of present study was to know human knowledge and attitude toward urban birds in Faisalabad city, Pakistan. The study conducted in four consecutive months: November 2019 to February 2020. Population of birds was noted from eight residential towns of Faisalabad city, data were collected through questionnaire. Faisalabad has a reasonably large population of birds and present data show that, there is a significant difference between favorite bird of residential areas and institutions. The pigeon received the most likeness in bird population among residential area residents, while the myna received the least. The most popular bird in Faisalabad institutions was the sparrow, while the least popular bird was the common myna. Bird adaptation percentage of residential areas and institutional areas of Faisalabad was the highest for parrot and sparrow respectively. People in residential areas and institutions, on the other hand, adapted least to common myna. It is concluded that people of the study area like birds and offered food and high population of birds are present in study area.
\end{abstract}

Keywords: population, dynamics, sparrow, urban, gender.

\begin{abstract}
Resumo
Os pássaros são indicadores muito valiosos da riqueza de espécies e padrões endêmicos em um determinado ecossistema, o que acaba ajudando o cientista a medir a degradação ambiental. O objetivo do presente estudo foi conhecer o conhecimento humano e a atitude em relação às aves urbanas na cidade de Faisalabad, Paquistão. O estudo foi conduzido em quatro meses consecutivos: novembro de 2019 a fevereiro de 2020 . A população de pássaros foi observada em oito cidades residenciais da cidade de Faisalabad, os dados foram coletados por meio de questionário. Faisalabad tem uma população razoavelmente grande de pássaros, e os dados atuais mostram que há uma diferença significativa entre as aves favoritas de áreas residenciais e instituições. 0 pombo recebeu mais semelhanças na população de pássaros entre os residentes de áreas residenciais, enquanto o myna recebeu menos. A ave mais popular nas instituições de Faisalabad era o pardal, enquanto a ave menos popular era o myna comum. A porcentagem de adaptação de pássaros em áreas residenciais e institucionais de Faisalabad foi a mais alta para papagaios e pardais, respectivamente. As pessoas em áreas residenciais e instituições, por outro lado, se adaptaram menos ao myna comum. Conclui-se que pessoas da área de estudo como pássaros e alimentos oferecidos e alta população de pássaros estão presentes na área de estudo.
\end{abstract}

Palavras-chave: população, dinâmica, pardal, urbano, gênero.

\section{Introduction}

Birds are very valuable indicators of species richness (Khan et al., 2021) and endemic patterns in a specified ecosystem, which eventually help the scientist to measure the environmental degradation (Gregory et al., 2003; Sinha et al., 2019; Ali et al., 2020). Moreover, introduced bird species offer unique opportunities to study evolution in new environments and, particularly, to understand that how genetic diversity changes with range expansion (Keller and Taylor, 2008). The house sparrow (Passer domesticus) introduced worldwide by anthropogenic activity, so, it is

*e-mail: altaf_mughal450@yahoo.com

Received: February 28, 2021 - Accepted: May 11, 2021 
one of the most prolific and successful way to introduced bird species in the world (Rajashekar and Venkatesha, 2008; Bibi et al., 2019). Although it is native to Eurasia but due to inherited traits, it dominated and successfully exploited urban areas under diverse climatic conditions, which have also resulted at some places in repelling indigenous competitor avifauna (De Laet and Summers-Smith, 2007; MacGregor-Fors et al., 2017).

There are increasing evidences that house sparrow populations are declining throughout the world both in rural and urban areas, although stable populations have also been reported in some places (Balmori and Hallberg, 2007; De Laet and Summers-Smith, 2007; Chamberlain et al., 2007; Ghosh et al., 2010; Seress et al., 2012; Khera et al., 2010; Kler et al., 2015). Population of $P$. domesticus have vanished in recent times from Brussels (De Laet, 2004), declines of $P$. domesticus were also documented in Dublin (Prowse, 2002). The well-noted alters have present in UK, where 60 percent decline documented in the population of $P$. domesticus from 1994 to 2004 (Raven et al., 2005). This decline was widespread enough to classify the above mentioned species as being of special concern in the UK, and of conservation concern in Europe (De Laet and Summers-Smith, 2007; Murgui and Macias, 2010)

The primary cause of this decline had not ascertained yet, however, a number of hypothesis been put forth (Kler et al., 2015). These included predation competition, lack of nest sites, disease, food including seeds that sustain the birds throughout the year, the invertebrates that are required by the house sparrows for rearing its young ones, and the pollution (Ghosh et al., 2010). Moreover, increased predator density may have reduced the breeding success of house sparrow via indirect and sub-lethal effects such as decreased foraging efficiency (Beckerman et al., 2007). Urbanization and behavior of urban dwellers can also have profound effects on the function and organization of urban ecosystem that can ultimately affect the communities of birds (Qureshi et al., 2010). Urbanization act as doubleedged sword for wildlife. On one edge, urbanization can destroy and fragment the natural ecosystems, degrade and alter ecosystem processes, and modify natural disturbance regimes. On the other hand, urbanization can create social and economic opportunities, centers of art and culture, and truly unique ecological spaces through design (Ubaidullah, 2004; Shaw et al., 2008; Murgui and Macias, 2010; Müller et al., 2013).

Faisalabad is the third most populous city of Pakistan with the highest human immigration rate from other small cities and towns (Mazhar and Jamal, 2011). Several studies reported in Pakistan to understand the population dynamics, ecology and genetic diversity of birds (Beg et al., 1982; Mustafa et al., 2015; Ubaidullah, 2004; Ahmad et al., 2015; Hakeem et al., 2017; Haider et al., 2017; Rauf at al., 2017; Bashir et al., 2018; Batool et al., 2019; Mughal et al., 2020), however, there is not study yet, which considered the socioeconomic factors along with distribution factors in urban settlements. Keeping in view the above scenario, present research was conducted to know human knowledge and attitude toward urban birds in Faisalabad city, Pakistan.

\section{Materials and Methods}

Present study conducted in urban areas of Faisalabad (3125'0.120"N and 734'59.880"E) which is the third biggest city of Pakistan. The total area of Faisalabad District is $5,856 \mathrm{~km}^{2}$ (2,261 sq. mi). However, the city covers almost $1,230 \mathrm{~km}^{2}$ (470 sq. mi) whereas the surroundings include more than $16,000 \mathrm{~km}^{2}$ (6,200 sq. mi). The weather conditions in the city regularly observed by the Pakistan Meteorological Department. The Köppen-Geiger climate classification system has categorized Faisalabad as a hot climate. Average annual rainfall is around $375 \mathrm{~mm}$ (14.8 inches) and it is extremely seasonal.

\subsection{Urban dwellers' data collection and study area}

The preliminary surveys conducted in urban towns of Faisalabad. For that purpose, three types of questionnaires were prepared in English for three different types of urban dwellers that are living/working or visiting varied form of land occupations: residential areas, parks and government institutes including schools, colleges and universities. From residential areas, municipal map was used to select 6-8 respondents randomly from each town (Figure 1). Eight towns in Faisalabad city are Lyallpur Town, Madina Town, Jinnah Town, Iqbal Town, Chak Jhumra Town, Jaranwala Town, Samundri Town and Tandliawala Town. Second type of questionnaire was used to select randomly the respondents from two major city parks of Faisalabad: Gutwala Park and Jinnah Park. The random visitors selected in the morning from 10:00 to 12:00 AM and in the evening from 4:00 to 6:00 PM in month of November to January to fill the questionnaires. For third type of questionnaire, respondents that are working or studying in different institutions were selected randomly i.e. University of Agriculture, Government College University, Government College Women University, and different colleges and schools. The interviews took for collecting the information regarding socio-economic characteristics of respondents, behavior of the people towards birds and problems facing by the sparrows.

\subsection{Estimation of house sparrow in urban areas}

Total count method in a fixed size square quadrate ( $10 \mathrm{~m} \times 10 \mathrm{~m}$ ) employed to estimate the population of birds in different urban areas for Faisalabad city. Field visits in the morning time between 10:00 AM and 12:00 AM made and field data sheet used to record field observations and birds populations. Four field tours carried out to collect data during different days of each month mostly Sunday in towns (one tour/week) and study continued for four consecutive months: November, December, January and February. Data were collected by single person. Special cares were taken in consideration do not to disturb birds during counting. Binocular and spotting scopes were used for assistance in counting. Areas with eagles/predators were exempt for sampling and counting not done during rainy or foggy days as well. Detailed procedure and precautions took about counting the house sparrow as described in literature (Babu et al., 2012). 


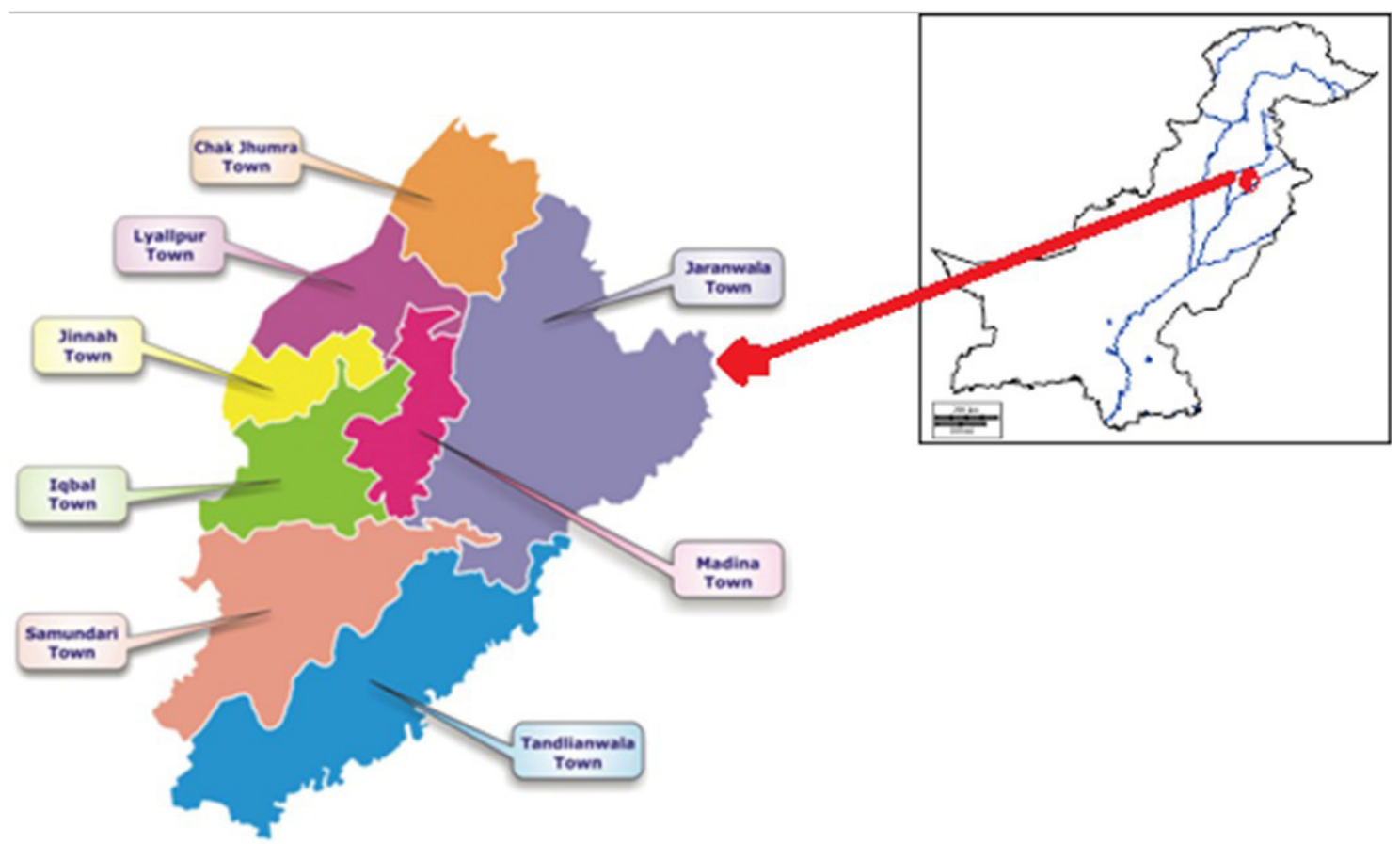

Figure 1. Map of urban area of Faisalabad city with demarcation of eight different towns.

Sixteen quadrates ( 4 quadrates/month) for each town and total 128 quadrates during 4 months were analyze in residential areas. Similarly, 32 quadrates (4 quadrates/ month/park during 4 months and for 2 parks) from parks and 128 quadrates from institutions as well (4 quadrates/ month/institutions during 4 months and 8 sites).

\subsection{Data analysis}

All the data obtained analyzed in IBM SPSS statistics 22 Software. Averages and standard error for all the data were calculated and demonstrated in graphs made in MS-Excel 2010. Population of house sparrow was calculated per hectare $\left(10000 \mathrm{~m}^{2}\right)$ from $100 \mathrm{~m}^{2}$ quadrate and presented in the tables as population per hectare.

\section{Results}

The data revealed that there was a significant difference for gender factor among residential areas, institutions and parks of Faisalabad (Figure 2a). For residential areas, numbers of male respondents were more as compared to female respondents. However, for educational institutions and parks, numbers of female respondents were higher as compared to male respondents. It was found that the most of the selected respondents during survey from city residential areas (37.03\%), institutions (48\%) and parks (42.6\%) had a minimum of 14 years of education (Figure $2 \mathrm{~b}$ ). The maximum proportion of respondents having at least 16 years of education (postgraduate category) were from institutions and the maximum proportion of respondents having the lowest education (primary category) were from residential areas, respectively.

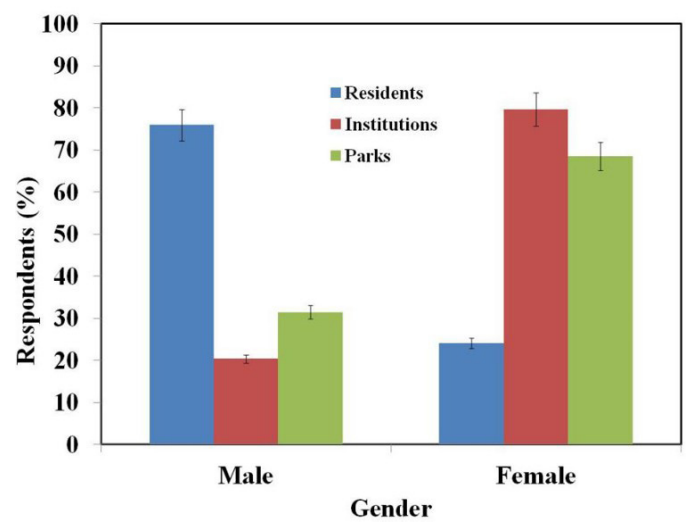

Figure 2a. Difference for gender factor among respondents from residential areas, institutions and parks

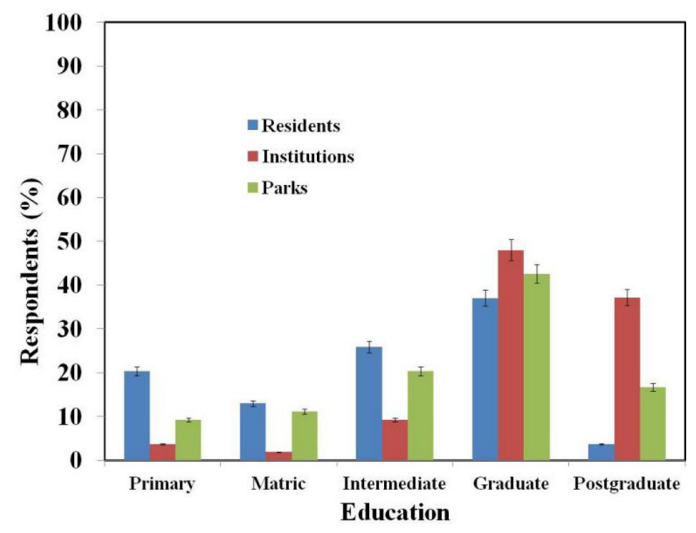

Figure $\mathbf{2 b}$. Education level of respondents. 

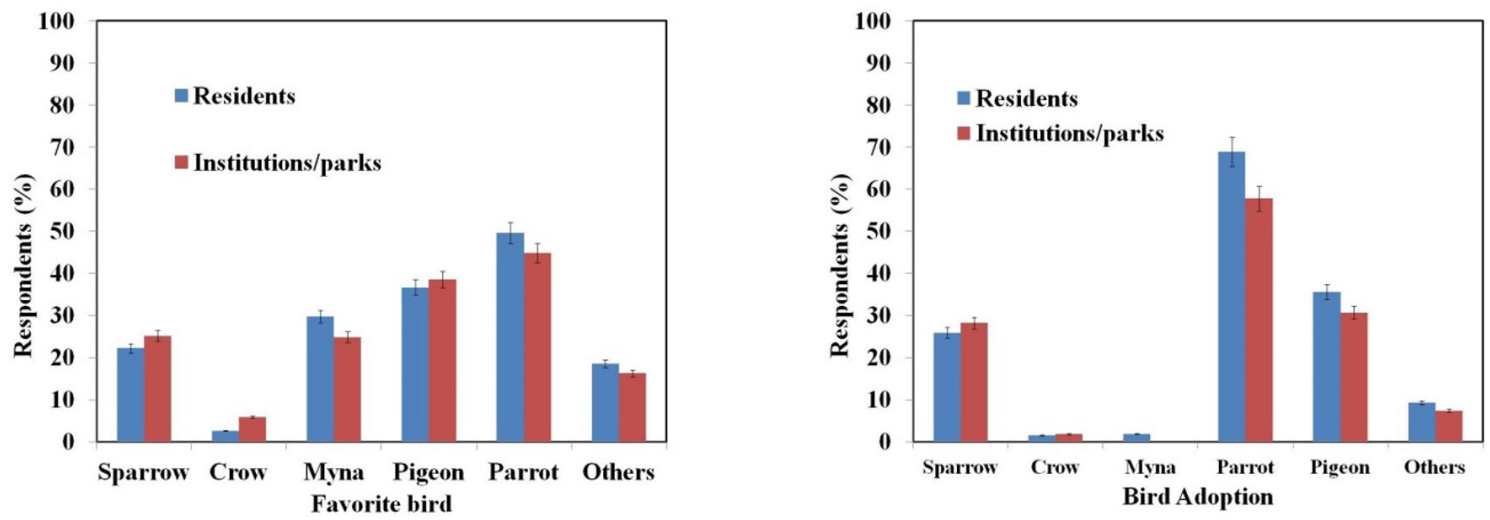

Figure 3. Likeness of birds by urban respondents. (a) Favorite birds of urban community; (b) willingness for bird adoption by urban respondents.

The core area of Faisalabad has a reasonably large population of house sparrows and present data show that, there is a significant difference between favorite bird of residential areas and institutions. The pigeon received the most likeness in bird population among residential area residents, while the myna received the least. The most popular bird in Faisalabad institutions was the sparrow, while the least popular bird was the common myna (Figure 3a). Bird adaptation percentage of residential areas and institutional areas of Faisalabad was the highest for parrot and sparrow respectively. People in residential areas and institutions, on the other hand, adapted least to common myna (Figure 3b).

Present study revealed that there was a significant difference for type of food provided to birds of residential areas and institutions. The most common type of food provided to birds in Faisalabad's residential areas was grain and seeds. Similarly, grain and seeds were the most abundant foods provided to birds at Faisalabad institutions, while fruits were the least abundant (Figure 4).

The core area of Faisalabad supports a reasonably large population of house sparrows and studies reveal that 96 percent of peoples who live in residential areas feed birds and only 4 percent of people do not. Only 20 percent of people did not provide space to the birds living in their homes, while the rest did. House sparrows are liked by 86 percent of people who live in residential areas, while a minority dislikes them. However, higher values for sparrow likeness and their nest were observed from residential areas, institutions and parks as well (Table 1 ). A higher proportion of people from residential area, institutions and parks provide food to house sparrow living in their homes, while the lowest proportion did not. People in residential areas and institutions are more likely to be aware of the breeding season of the house sparrow, whereas people in parks are less likely to be aware. High numbers of people from residential area support sparrow as compared to visitors of park and institutions.

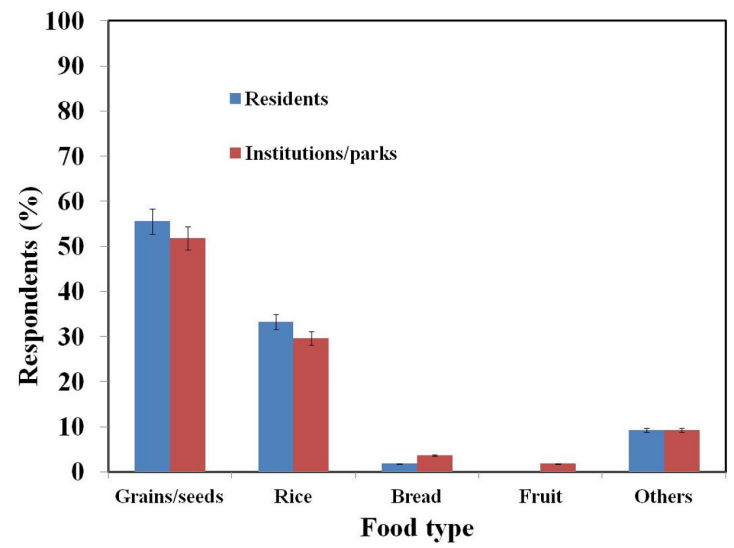

Figure 4. Types of food provided by urban community to birds.

Table 1. Percentage values of questioner regarding House Sparrow and other avian fauna from peoples of different towns, parks and educational institutes of Faisalabad, Pakistan.

\begin{tabular}{lccc}
\hline \multicolumn{1}{c}{ Questions } & $\begin{array}{c}\text { Residential } \\
\text { area Yes } \\
(\%)\end{array}$ & $\begin{array}{c}\text { Parks Yes } \\
\text { (\%) }\end{array}$ & $\begin{array}{c}\text { Institutions } \\
\text { Yes (\%) }\end{array}$ \\
\hline Feed to birds & 96 & 25 & 18 \\
$\begin{array}{l}\text { Provided Space } \\
\text { to birds }\end{array}$ & 80 & -- & 10 \\
Disturbed birds & 18 & 5 & 85 \\
Birds likeness & 86 & 75 & 65 \\
$\begin{array}{l}\text { Nest presence } \\
\text { of birds }\end{array}$ & 48 & 72 & 65 \\
Nest likeness & 25 & 64 & 75 \\
Support birds & 78 & 45 & 52 \\
$\begin{array}{l}\text { Breeding } \\
\text { Knowledge }\end{array}$ & 56 & 26 & 21 \\
Sound-likeness & 86 & 12 & 18 \\
\hline
\end{tabular}


Table 2. Average value of birds counts at different towns of district Faisalabad, Pakistan.

\begin{tabular}{|c|c|c|c|c|c|c|}
\hline SR. No & Towns & November & December & January & February & Mean \pm SD \\
\hline 1 & Lyallpur Town & $4.30 \pm 1.90$ & $5.20 \pm 2.30$ & $3.2 \pm 1.20$ & $3 \pm 0.90$ & $3.9 \pm 1.60$ \\
\hline 2 & Madina Town & $4.5 \pm 2.80$ & $4 \pm 1.40$ & $3.3 \pm 1.40$ & $4 \pm 2.80$ & $3.95 \pm 2.10$ \\
\hline 3 & Jinnah Town & $2.3 \pm 1.20$ & $2.7 \pm 0.80$ & $2.5 \pm 1.40$ & $3 \pm 1.50$ & $2.6 \pm 1.23$ \\
\hline 4 & Iqbal Town & $5.7 \pm 2.60$ & $3.3 \pm 1.50$ & $4.3 \pm 2.40$ & $4 \pm 1.40$ & $4.3 \pm 1.98$ \\
\hline 5 & Chak Jhumra Town & $3.5 \pm 1.40$ & $3.7 \pm 1.20$ & $2.5 \pm 1.040$ & $3 \pm 0.890$ & $3.2 \pm 1.13$ \\
\hline 6 & Jaranwala Town & $5.5 \pm 2.10$ & $6.5 \pm 1.90$ & $4.7 \pm 2.10$ & $6.2 \pm 2.040$ & $5.7 \pm 2.03$ \\
\hline 7 & Samundri Town & $4 \pm 1.40$ & $3.5 \pm 0.50$ & $3.8 \pm 1.30$ & $4.3 \pm 1.50$ & $3.9 \pm 1.20$ \\
\hline 8 & Tandliawala Town & $4 \pm 0.90$ & $4 \pm 1.10$ & $4.8 \pm 0.80$ & $5 \pm 1.30$ & $4.5 \pm 1.03$ \\
\hline Average & & $4.2 \pm 1.80$ & $4.11 \pm 1.30$ & $3.6 \pm 1.50$ & $4.06 \pm 1.50$ & $4 \pm 1.50$ \\
\hline
\end{tabular}

Note: $\mathrm{SR}=$ Serial, $\mathrm{SD}=$ Standard deviation

Table 3. Average value of birds counts at different parks of district Faisalabad, Pakistan.

\begin{tabular}{ccccccc}
\hline SR. No & Parks & November & December & January & February & Mean \pm SD \\
\hline 1 & Company Park & $12.2 \pm 2.7$ & $11.6 \pm 2.2$ & $11.9 \pm 2.6$ & $13.2 \pm 2.8$ & $12.2 \pm 2.5$ \\
2 & Gutwala Park & $13.6 \pm 2.6$ & $13.9 \pm 2.5$ & $12.6 \pm 3.1$ & $12.5 \pm 2.3$ & $13.2 \pm 2.6$ \\
Average & & $12.9 \pm 2.6$ & $12.8 \pm 2.4$ & $12.3 \pm 2.9$ & $12.9 \pm 2.6$ & $12.7 \pm 2.6$ \\
\hline
\end{tabular}

Note: $\mathrm{SD}=$ Standard deviation

Table 4. Average value of birds counts at different institutes of district Faisalabad, Pakistan.

\begin{tabular}{ccccccc}
\hline SR. No & Institutes & November & December & January & February & Mean \pm SD \\
\hline 1 & UAF & $8.7 \pm 1.40$ & $9.7 \pm 2.10$ & $8.7 \pm 1.80$ & $7.85 \pm 1.30$ & $8.75 \pm 1.60$ \\
2 & GCUF & $8.4 \pm 1.60$ & $8.9 \pm 1.80$ & $9.0 \pm 0.80$ & $8.3 \pm 1.60$ & $8.6 \pm 1.50$ \\
3 & GCUWF & $8.1 \pm 1.30$ & $8.6 \pm 2.20$ & $8.4 \pm 2.10$ & $8.6 \pm 1.90$ & $8.4 \pm 1.90$ \\
4 & Others & $8.4 \pm 1.90$ & $8.6 \pm 2.60$ & $9.1 \pm 1.80$ & $8.6 \pm 2.20$ & $8.7 \pm 2.10$ \\
Average & & $8.4 \pm 1.50$ & $8.9 \pm 2.10$ & $8.8 \pm 1.70$ & $8.3 \pm 1.70$ & $8.6 \pm 1.70$ \\
\hline
\end{tabular}

Note: $\mathrm{SD}=$ Standard deviation

The average numbers of birds in residential areas, parks and institutions were estimate per hectare. It was evaluated that more birds were present in Jaranwala town as compared to other towns, while the least population noted in Jinnah town as mentioned in Table 2, respectively. However, more birds per hectare were present in Gutwala Park, while the least population found in Company Park (Table 3). Similarly, average numbers of birds in educational institutions per hectare given in Table 4 . It was calculated that more birds were present in University of Agriculture, Faisalabad while, least population in GCWUF, respectively.

\section{Discussion}

In Pakistan, it is a male dominant society where males are heads of houses (Ullah and Skelton, 2013) and female heads houses are low in numbers with financial instability (Mohiuddin and Alderman, 1989). Data were collected from both male and female. Although, in residential area data collection done by a female interviewer but she could not able to convince females as much as from institution and parks. However, female respondent population was more in institutions and park as compared to males. Although, literacy rate in Pakistan is very low but it is more in cities than rural area (Andrabi et al., 2002; Harrison, 2004; Rehman et al., 2015).

Scott (1993) reported that urban development leads to an increase in avian number, while reducing species diversity, indicating that pattern of avian community changes with urbanization. Summers-Smith (2005) estimated that the replacement of the horse by the automobile as a means of transport resulted in urban decline of the house sparrow, which ultimately removed a great source of food and nesting material from the sparrow as well.

As compared to urban area, agricultural area provides abundance of food in the form of grains and insects (Balmori and Hallberg, 2007). Birds prefer areas containing high ratio of invertebrates at the start of breeding season. Because in array to feed their young one's they depend on high protein feed viz., insects and other invertebrates, however, adults are chiefly seed eaters. Therefore, the availability of grains in the urban areas goes in favors of Rock Pigeon, but might not in favors of House Sparrow 
that needs additional supply of insects for brooding of young ones. It had been suggested that competition of the house Sparrow with Pigeons might be possible factor for declining population of the birds as well (Altaf, 2016; Altaf et al., 2018). Chamberlain et al. (2007) also reported that the density of House Sparrow declines as private gardens providing nesting space in hedges- decline.

According to present study, there was the shortage of urban parks and garden as well as severe climatic conditions and noise pollution were probable aspects eliminated breeding and nesting sites that caused the avian to migrate. Similarly, Summers-Smith (2003) documented that unavailability of proper nesting sites in buildings that must have been responsible for decline in population of house sparrow. Similarly, Heij (2001) reported four possible causes of declines in urban areas in Netherlands. First, the use of roof tiles has resulted into decrease in the numbers of nesting places. Second, in recent decades, cleanliness of cities leads to scarcity of nesting material. Third, a gradual fall in food abundance for the same reason and at last an increase in predation.

Lot of studies had suggested that in populated areas absence of insects might be vital factor to decline of house sparrow populations (Peach et al., 2008; Summers-Smith, 2003). It had also been confirmed that more than $50 \%$ reduction in reproduction of insects with short-term exposure of pulsed mobile phone radiation an important declining factor for population (Panagopoulos et al., 2004). Another important factor regarding declining House Sparrow population is signal emitting towers that were installed in so large number in the urban areas (Balmori, 2003; Balmori and Hallberg, 2007).

Environmental changes may further affect the population trend of the House Sparrow as well (Siriwardena et al., 1999). The present study was limited to just four months and it does not provide enough data to understand the population trends of the house sparrow its interrelationship with other co-existing species. That is why, further studies needed to analyze occurrence of the house sparrow in the area of study. Local community involvement in monitoring will not only ensure sustainability of the program, but will also help in gaining public support for the conservation of important species.

\section{Acknowledgements}

We are grateful to university of agriculture Faisalabad for funding through a faculty development grant. Finally, we thank to people of Faisalabad city for taking the time and effort to report the house sparrow observation with us.

\section{References}

AHMAD, S., JABEEN, F., KHAN, H.A., SAMIULLAH, K., YAQUB, S., MUBARIK, M.S.,ZAHOOR, M.K., SALEEM,Z. and SHAFIQUE, A.M.M., 2015. Effectivness of anthraquinone and methylanthranilate against house sparrow (Passer domesticus) from wheat seeds and seedlings in caged conditions in Pakistan.Journal of Biodiversity and Environmental Sciences., vol. 6, pp. 326-334.
ALI, A., KHAN, M.S.H. and ALTAF, M., 2020. Analysis of anthropogenic activities on avian diversity along the coastal landscape of Sindh.Pakistan Journal of Wildlife and Ecology., vol. 4, pp. 94-110.

ALTAF, M., 2016. Assessment of avian and mammalian diversity at selected sites along river Chenab.University of Veterinary and Animal Sciences, Lahore-Pakistan, 156 p. Thesis in Wildlife \& Ecology.

ALTAF, M., JAVID, A., KHAN, A.M., KHAN, M., UMAIR, M. and ALI, Z., 2018. Anthropogenic impact on the distribution of the birds in the tropical thorn forest, Punjab, Pakistan.Journal of AsiaPacific Biodiversity, vol. 11, no. 2, pp. 229-236. http://dx.doi. org/10.1016/j.japb.2018.03.001.

ANDRABI, T., DAS, J. and KHWAJA, A.,2002. The Rise of Private Schooling in Pakistan: catering to the urban elite or educating the rural poor?Cambridge: World Bank and Harvard University.

BABU, I., NAEEM, M.M., BUKHARI, M., KHALIL-UR-REHMAN, S.A. and BUTT, I., 2012. Population Dynamics and Woodland Characteristics of Avian Fauna at the Chhanga Manga Forest in Lahore, Pakistan.World Journal of Zoology., vol. 7, pp. 203-209.

BALMORI, A., 2003. Birds and mobile telephony. Preliminary results of the effects of electromagnetic waves on urban fauna.Ecology, vol. 36, pp. 40-42.

BALMORI, A. and HALLBERG, A., 2007. The urban decline of the house sparrow (Passer domesticus): a possible link with electromagnetic radiation.Electromagnetic Biology and Medicine, vol. 26, no. 2, pp. 141-151. http://dx.doi.org/10.1080/15368370701410558. PMid:17613041.

BASHIR, S.M., RASHID, Z., MUMTAZ, B., ALTAF, M., RAUF, K., HAIDER, R., SAFEER, B., FAROOQ S.I., SAFDAR, L., MANZOOR, I., YASRUB, S. and IFTIKHAR, A., 2018. Assessment of behavioral ecology, folklore and medicinal uses of Barn Swallow (Hirundorustica) in district Bagh-Pakistan.Journal of Wildlife and Ecology, vol. 2, no. 2, pp. 13-21.

BATOOL, F., KHAN, H. and SAIF-UR-REHMAN, M., 2019. Genetic diversity analysis in house sparrow (Passer domesticus) using microsatellite markers in Punjab, Pakistan.Journal of Animal and Plant Sciences, vol. 29, pp. 343-348.

BECKERMAN, A.P., BOOTS, M. and GASTON, K.J., 2007. Urban bird declines and the fear of cats.Animal Conservation, vol. 10, no. 3, pp. 320-325. http://dx.doi.org/10.1111/j.1469-1795.2007.00115.x.

BEG, M., RANA, S. and AKHTAR, S., 1982. Food of House Sparrow in the cultivations of Faisalabad. Pakistan.Journal of Agricultural Sciences, vol. 19, pp. 122-129.

BIBI, S., JADOON, A. and REHMAN, A., 2019. Study of population and breeding biology of house sparrow (Passer domesticus) in district Haripur, Khyber Pakhtunkhwa, Pakistan.Journal of Wildlife and Ecology, vol. 3, pp. 16-21.

CHAMBERLAIN, D.E., TOMS, M.P., CLEARY-MCHARG, R. and BANKS, A.N., 2007. House sparrow (Passer domesticus) habitat use in urbanized landscapes.Journal of Ornithology, vol. 148, no. 4, pp. 453-462. http://dx.doi.org/10.1007/s10336-007-0165-x.

DE LAET, J., 2004. De Huismus: verontrustendnieuws, in de steden is het nietvijf maar Tweevoortwaalf.Mens Vogel, vol. 42, pp. 238-245.

DE LAET, J. and SUMMERS-SMITH, J., 2007. The status of the urban house sparrow Passer domesticus in north-western Europe: a review.Journal of Ornithology, vol. 148, no. S2, pp. 275-278. http://dx.doi.org/10.1007/s10336-007-0154-0.

GHOSH, S., KIM, K.-H. and BHATTACHARYA, R., 2010. A survey on house sparrow population decline at Bandel, West Bengal, India.Journal of the Korean Earth Science Society., vol. 31, no. 5, pp. 448-453. http://dx.doi.org/10.5467/JKESS.2010.31.5.448.

GREGORY, R.D., NOBLE, D., FIELD, R., MARCHANT, J., RAVEN, M. and GIBBONS, D., 2003. Using birds as indicators of biodiversity. Ornishungarica., vol. 12, pp. 11-24. 
HAIDER, R., ALTAF, M., RASHEED, Z., RAUF, K., MUMTAZ, B., ALTAF, M., SHABIR, M., HAKEEM, F. and IFTIKHAR, A., 2017. Assessment of behavioral study, human activities impacts and interaction with white cheeked bulbul (Pycnonotusleucotis) in district Bagh, Azad Jammu and Kashmir, Pakistan.Wildlife and Ecology, vol. 1, no. 2, pp. 17-24.

HAKEEM, F., ALTAF, M., MANZOOR, S., RAUF, K., MUMTAZ, B., BASHIR, M., HAIDER, R., FAROOQ S.I., SAFDAR, L. and ALTAF, M., 2017. Assessment of behavioral study, human activities impacts and interaction with Streak laughingthrush (Trochalopteronlineatum) in district Bagh, Azad Jammu and Kashmir-Pakistan.Journal of Wildlife and Ecology, vol. 1, no. 3, pp. 1-7.

HARRISON, S., 2004. Degree vs diploma: can education to degree level really produce more confident nurses and better patient outcomes?Nursing Standard, vol. 18, pp. 12-14.

HEIJ, C.J., 2001. Mussen in de knel.Nature, vol. 3, pp. 76-78. (in Dutch).

KELLER, S.R. and TAYLOR, D.R., 2008. History, chance and adaptation during biological invasion: separating stochastic phenotypic evolution from response to selection.Ecology Letters, vol. 11, no. 8, pp. 852-866. http://dx.doi.org/10.1111/j.1461-0248.2008.01188.x. PMid:18422638.

KHAN, R.U., PANHWAR, W.A., MEMON, K.H. and LARIK, S.A., 2021. Effects of lead on feathers of grey francolin Francolinuspondicerianus.Journal of Wildlife and Ecology., vol. 5, pp. 7-12.

KHERA, N., DAS, A., SRIVASATAVA, S. and JAIN, S., 2010. Habitatwise distribution of the House Sparrow (Passer domesticus) in Delhi, India.Urban Ecosystems, vol. 13, no. 1, pp. 147-154. http:// dx.doi.org/10.1007/s11252-009-0109-8.

KLER, T.K., KUMAR, M. and DHATT, J.S., 2015. Study on the population of house sparrow (Passer domesticus) in urban and rural areas of Punjab.International Journal of Advanced Research, vol. 3 , pp. 1339-1344.

MACGREGOR-FORS, I., QUESADA, J., LEE, J.G. and YEH, P.J., 2017. Space invaders: house sparrow densities along three urban agricultural landscapes.Avian Conservation \& Ecology, vol. 12, no. 2, art11. http://dx.doi.org/10.5751/ACE-01082-120211.

MAZHAR, F. and JAMAL, T., 2011. Temporal Population Growth of Faisalabad City.Pakistan Journal of Science, vol. 63, pp. 249-251.

MOHIUDDIN, Y. and ALDERMAN, H., 1989. Female-headed Households and Urban Poverty in Pakistan.Pakistan Development Review, vol. 28, pp. 759-775.

MUGHAL, S., PERVAZ, M., BASHIR, S.M. and SHAMASHAD, S.S., 2020 Assessment of diversity and ethnopharmacological uses of birds in Chakar, Hattian Bala district, Azad Jammu and Kashmir -Pakistan.Journal of Wildlife and Ecology., vol. 4, pp. 35-44.

MÜLLER, N., IGNATIEVA, M., NILON, C.H., WERNER, P. and ZIPPERER, W.C., 2013. Patterns and trends in urban biodiversity and landscape design. In: T.ELMQVIST, M.FRAGKIAS, J.GOODNESS, B.GÜNERALP, P.J.MARCOTULLIO, R.I.MCDONALD, S.PARNELL, M.SCHEWENIUS, M.SENDSTAD, K.C.SETO, and C.WILKINSON, eds. Urbanization, biodiversity and ecosystem services.Dordrecht: Springer, pp.123-174. http://dx.doi.org/10.1007/978-94-0077088-1_10.

MURGUI, E. and MACIAS, A., 2010. Changes in the House Sparrow Passer domesticus population in Valencia (Spain) from 1998 to 2008.Bird Study, vol. 57, no. 3, pp. 281-288. http://dx.doi. org/10.1080/00063651003716762.

MUSTAFA, I., ARIF, N., HUSSAIN, S.M., MALIK, I.U., JAVID, A., ULLAH, M.I., ASIF, S., KHAN, M.R., WAQAS, A., EQANI, S.A.M., IRUM, S. and AHMED, H., 2015. Population Dynamics of house sparrow (Passer domesticus) and house crow (Corvussplendens) in Punjab (District Sargodha), Pakistan.Pakistan Journal of Zoology, vol. 47, pp. 1147-1155.

PANAGOPOULOS, D.J., KARABARBOUNIS, A. and MARGARITIS, L.H., 2004. Effect of GSM $900 \mathrm{MHz}$ mobile phone radiation on the reproductive capacity of Drosophila melanogaster.Electromagnetic Biology and Medicine, vol. 23, no. 1, pp. 29-43. http://dx.doi. org $/ 10.1081 / J B C-120039350$.

PEACH, W.J., VINCENT, K.E., FOWLER, J.A. and GRICE, P.V., 2008. Reproductive success of house sparrows along an urban gradient.Animal Conservation, vol. 11, no. 6, pp. 493. http:// dx.doi.org/10.1111/j.1469-1795.2008.00209.x.

PROWSE, A., 2002. The urban decline of the house sparrow.British Birds, vol. 95, pp. 144-145.

QURESHI, S., BREUSTE, J.H. and LINDLEY, S.J., 2010. Green space functionality along an urban gradient in Karachi, Pakistan: a socio-ecological study.Human Ecology, vol. 38, no. 2, pp. 283294. http://dx.doi.org/10.1007/s10745-010-9303-9.

RAJASHEKAR, S. and VENKATESHA, M., 2008. Occurrence of house sparrow, Passer domesticus indicus in and around Bangalore. Current Science, vol. 94, pp. 446-449.

RAUF, K., ALTAF, M., MUMTAZ, B., ALTAF, M., HAIDER, R., SAFEER, B., FAROOQ, S.I., SAFDAR, L., MANZOOR, M., YASRUB, S., BASHIR, S.M. and IFTIKHAR, A., 2017. Assessment of behavior, distribution, ecology and interaction study of Cinnamon Tree Sparrow (Passer rutilans) in district Bagh-Pakistan.Journal of Wildlife and Ecology, vol. 1, no. 3, pp. 43-49.

RAVEN, M.J., NOBLE, D.G. and BAILLIE, S.R., 2005. The breeding bird survey 2004.Thetford, UK: The British Trust for Ornithology, vol. 2, pp. 139-144.

REHMAN, A., JINGDONG, L. and HUSSAIN, I., 2015. The provincewise literacy rate in Pakistan and its impact on the economy. Pacific Science Review B.Humanities and Social Sciences., vol. 1, pp. 140-144.

SCOTT, T.A., 1993. Initial effects of housing construction on woodland birds along the wildland urban interface. In: J.E.KEELEY, ed. Interface between ecology and land development in California.Los Angeles: Southern California Academy of Sciences, pp 181-187.

SERESS, G., BOKONY, V., PIPOLY, I., SZEP, T., NAGY, K.R. and LIKER, A.S., 2012. Urbanization, nestling growth and reproductive success in a moderately declining house sparrow population. Journal of Avian Biology, vol. 43, no. 5, pp. 403-414. http://dx.doi. org/10.1111/j.1600-048X.2012.05527.x.

SHAW, L.M., CHAMBERLAIN, D. and EVANS, M., 2008. The House Sparrow Passer domesticus in urban areas: reviewing a possible link between post-decline distribution and human socioeconomic status.Journal of Ornithology, vol. 149, no. 3, pp. 293-299. http://dx.doi.org/10.1007/s10336-008-0285-y.

SINHA, A., CHATTERJEE, N., ORMEROD, S.J., ADHIKARI, B.S. and KRISHNAMURTHY, R., 2019. River birds as potential indicators of local-and catchment-scale influences on Himalayan river ecosystems.Ecosystems and People., vol. 15, no. 1, pp. 90-101. http://dx.doi.org/10.1080/26395916.2019.1591508.

SIRIWARDENA, G.M., BAILLIE, S.R. and WILSON, J.D., 1999. Temporal variation in the annual survival rates of six granivorous birds with contrasting population trends.The Ibis, vol. 141, no. 4, pp. 621-636. http://dx.doi.org/10.1111/j.1474-919X.1999.tb07370.x.

SUMMERS-SMITH, J.D., 2003. The decline of the House Sparrow: a review.British Birds, vol. 96, pp. 439-446.

SUMMERS-SMITH, J.D., 2005. Changes of the House Sparrow population in Britain.Int Stud Sparrows, vol. 30, pp. 23-37.

UBAIDULLAH, M., 2004. Losses due to House Sparrow to wheat crop in Central Punjab.International Journal of Agriculture and Biology, vol. 6, pp. 541-543.

ULLAH, H. and SKELTON, C., 2013. Gender representation in the public sector schools textbooks of Pakistan.Educational Studies, vol. 39, no. 2, pp. 183-194. http://dx.doi.org/10.1080/030556 98.2012.702892. 